Madrygal. Revista de Estudios Gallegos

ISSN: 1138-9664

\title{
David y Salomón ante la puerta del Paraíso: el reflejo moral del Antiguo Testamento en la catedral de Ourense (siglo XIII)
}

\author{
Natalia Conde Cid $^{1}$
}

Recibido: 17 de abril de 2016 / Aceptado: 5 de setembro de 2016

Resumen. El pórtico del Paraíso de la catedral de Ourense es un espacio destinado esencialmente a una función penitencial. Ofrece un programa visual que ayuda a que el fiel pecador pueda realizar un sincero acto de contrición, antes de traspasar la puerta para acceder al templo, entendida como Cristo, siguiendo el texto de san Juan 10, 9-10. En él se ubican las figuras de David, Salomón y nueve profetas, quienes aportan un destacable carácter moralizante dentro del contexto penitencial creado a partir del IV Concilio de Letrán de 1215, sin duda transmitido en el Tractatus de Poenitentia redactado por el obispo auriense don Lorenzo a comienzos del siglo XIII.

Palabras clave: Edad Media; Antiguo Testamento; penitencia; obispo Lorenzo; pórtico del Paraíso; catedral de Ourense.

\section{[gl] David e Salomón ante porta do Paraíso: o reflexo moral do Antigo Testamento na catedral de Ourense (século XIII)}

Resumo. O pórtico do Paraíso da catedral de Ourense é un espazo dedicado esencialmente a unha función penitencial. Ofrece un programa visual que axuda a que o fiel pecador poida realizar un acto sincero de contrición, antes de traspasar a porta para acceder ao templo, entendido como Cristo, seguindo o texto de san Xoán 10, 9-10. Nel sitúanse as figuras de David, Salomón e nove profetas, quen achegan un salientábel carácter moralizante dentro do contexto penitencial creado a partir do IV Concilio de Letrán de 1215, sen dúbida transmitido no Tractatus de Poenitentia redactado polo bispo auriense don Lorenzo a comezos do século XIII.

Palabras chave: Idade Media; Antigo Testamento; penitencia; bispo Lorenzo; pórtico do Paraíso; catedral de Ourense.

\section{[en] David and Solomon in the Portal of Paradise: A Moral Reflection Seen through the Old Testament in Ourense Cathedral $\left(13^{\text {th }} \mathrm{C}\right.$. $)$}

\begin{abstract}
The Portal of Paradise of Ourense Cathedral is essentially an area with a penitential function. It offers a visual frame that helps the faithful "sinner" make a sincere act of contrition before crossing the gate of the temple, which supposedly represents Christ himself according to the text of St. John 10, 9-10. Here one can find the statues of David, Solomon and nine prophets, which give it a remarkable moralizing character within the penitential context created at the Fourth Lateran Council of 1215, which was undoubtedly written down in the early thirteenth century in the Tractatus de Poenitentia by the Bishop of Ourense Don Lorenzo.

Keywords: Middle Ages; Old Testament; Penance; Bishop Lorenzo; Portal of Paradise; Ourense Cathedral.

Sumario. 1. ¿Qué es el Paraíso? 2. El Paraíso en la catedral de Ourense. 2.1. David: Domino in regnum uoccatus. 2.2. 2.2 Salomón: sapiens in iudicio, in sententia iustus. 3. Profetas y patriarcas del Antiguo Testamento. 4. El ritual del perdón. 5. Conclusión. 6. Referencias bibliográficas.
\end{abstract}

Como citar: Conde Cid, N. (2016): "David y Salomón ante la puerta del Paraíso: el reflejo moral del Antiguo Testamento en la catedral de Ourense (siglo XIII)", en Madrygal. Revista de Estudios Gallegos 19, 33-42.

Universidade de Santiago de Compostela, Departamento de Historia da Arte.
E-mail: natalia.conde@usc.es 


\section{1. ¿Qué es el Paraíso?}

En el capítulo primero del Génesis se narra la creación de la tierra y de la Humanidad, personificada en Adán y Eva; Dios les entrega el dominio y el poder sobre todas las criaturas para su subsistencia. Describe este texto el jardín del Edén o Paraíso que habitarán Adán y Eva como un espacio que posee luz y tinieblas, característicos del día y la noche, una tierra que produce hierba verde y todo tipo de árboles y frutos. Sin embargo la característica más relevante de este lugar es su descripción como frondoso vergel en el que nace la vida, tanto en la tierra como en el mar, ríos o en el cielo. Por eso las representaciones de este lugar durante la Edad Media se caracterizan por albergar una espesa vegetación, más o menos ordenada, entre la cual en ocasiones se cobijan pequeñas figuras de árboles o humanas.

Tras la expulsión se convierte en un espacio cerrado o acotado, siguiendo las indicaciones del Cantar de los Cantares: "Eres jardín cerrado hermana mía, esposa eres, jardín cercado, fuente sellada". De esta manera, las representaciones medievales se realizarán en su mayor parte siguiendo esta premisa, siempre que el espacio que la albergue lo permita (salterios, libros de horas, cartografías). Se perfila como un espacio cerrado por un alto muro, en el que habitan seres humanos alejados del dolor y por lo tanto, de la humanidad real a la que el pecado avocó al hombre; en el centro, la fuente de la que emanan los cuatro ríos (Bueno Sánchez 2008: 398).

En el caso de las representaciones escultóricas habilitadas sobre arquitectura (portadas de catedrales, capiteles, relieves) es más complicado el perfilado de un espacio acotado que acoja en su interior una cuantiosa vegetación con ríos y animales, por lo que suele reducirse únicamente a un simple y abundante follaje. Sobre este tema todavía se debate durante el siglo XIII, cuando santo Tomás de Aquino en su Summae Theologicae se cuestiona la existencia física o no del paraíso terrenal descrito en la Biblia. La manera de identificar este espacio suele ser a través de la figuración antropomorfa que puede encontrarse entre la vegetación: querubines flanqueando el acceso, Abraham con los justos en su seno, figuración humana de aquellos personajes que han sido salvados tras el Juicio Final, que en ocasiones se muestran como cabezas o bustos de los justos emergiendo de los árboles, en esa consideración de los bienaventurados como frutos de los árboles del Paraíso, entre otras variantes.

\section{El Paraíso en la catedral de Ourense}

El Paraíso auriense es representado en las arquivoltas del arco septentrional, como conclusión de un programa que comenzaría en la contraportada con las figuras monárquicas del Antiguo Testamento de David y Salomón para continuar por el arco meridional, donde del Juicio Final son salvadas una serie de almas bienaventuradas que dirigen sus pasos hacia el norte, donde se halla el Edén; en el otro extremo del arco sur se perfilan las penas del infierno, lugar adonde se dirigen las almas de los pecadores juzgados negativamente. Cristo Juez, acompañado por el arcángel san Miguel, proceden al juicio para dilucidar quiénes entrarán al paraíso (VENITE / B(e)N(e)DICT(i) / PATRIS M(e)I) y quiénes al infierno a través de la boca del Leviatán (ITE MALE / DICTI IN IG / NE ETERNUM), y dictan sentencia desde la clave del arco.

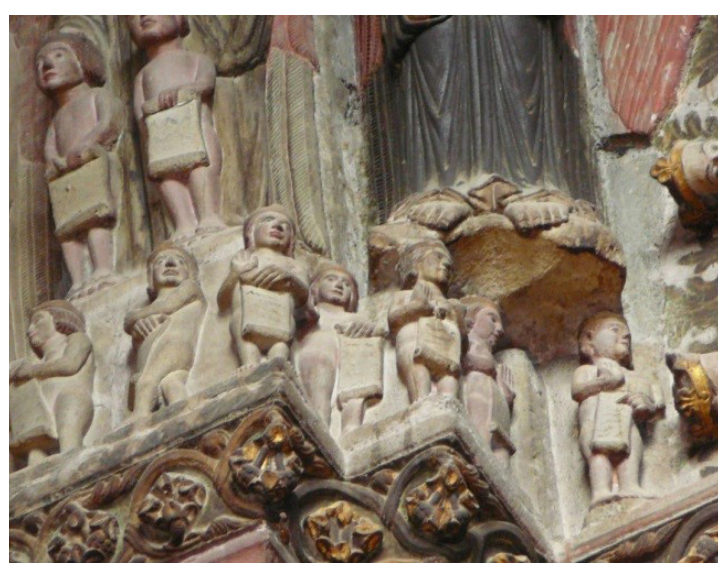

Fig. 1. Almas coronadas. Pórtico del Paraíso. Catedral de Ourense

Es iconografía ya conocida desde los años del románico, pues de este mismo modo se figura la separación de justos y pecadores en la puerta central de la portada occidental de la basílica de Saint-Denis de Paris (ErlandeBrandenburg 2007: 18). Esta separación se encuentra en la mayoría de las portadas del siglo XII donde se representa el Juicio Final o la Parusía de Cristo; sirva el ejemplo de SaintTrophime de Arles (Bouches-du-Rhône), cuya portada datada entre 1130-1160 alberga una serie de bienaventurados que caminan hacia 
su derecha donde les aguarda el Reino de los Cielos, mientras hacia su izquierda se dirigen los pecadores. Este acto se puede ver resumido en el texto de san Mateo 25, 46, donde se reflejan cuáles son los finales posibles para el ser humano según su comportamiento y acciones terrenales: "E irán estos a un castigo eterno, y los justos a una vida eterna".

El infierno es un espacio lúgubre, desordenado y caótico, reservado en todos los casos para aquellos que se negaron a seguir a Cristo, tal como lo describen los evangelistas san Lucas y san Mateo; para san Marcos sería, por añadidura, un lugar en donde el fuego no puede ser apagado (Guiance 2009: 130-131). Sin embargo, al otro lado, en ese movimiento en potencia hacia el Paraíso vacío situado en el otro extremo del pórtico, los bienaventurados son representados como almas puras al figurarse desnudos o únicamente con una túnica que los cubra. De esta manera, la iconografía de este arco meridional plasma la antesala de la llegada al Edén, Paraíso o Jerusalén Celeste, de aquellos a los que el Juez Supremo les ha concedido la salvación, la cual se materializa a través de la corona que portan sobre sus cabezas las figuras más cercanas al arco septentrional.

La representación figurativa del Juicio Final y la separación entre justos y pecadores admite numerosas variantes sobre el mismo tema. En Ourense, la orientación es similar -pero no igual- al pórtico de la Gloria compostelano, donde las almas salvadas rodean la figura de Cristo; todos aquellos bienaventurados se dirigen hacia la representación central de la Gloria. En Ourense, sin embargo, se plasma una variación sobre el tema principal del Juicio, pues las almas no se dirigen hacia el arco central, sino que la escena representada es un movimiento en potencia que discurre hacia el arco septentrional: tras el Juicio (arco meridional), las almas de la primera enjuta caminan hacia el arco central, donde las desaparecidas imágenes que albergase antes de su restauración en el siglo XVI proceden a su coronación; de esta manera, los bienaventurados discurren por la segunda enjuta y hacia el paraíso con una corona sobre sus cabezas, símbolo del triunfo victorioso al que han llegado tras una existencia virtuosa.

En el humanizado contexto artístico del siglo XIII, después de la representación del
Juicio, donde Cristo dicta la última sentencia, se hace habitual el contrapunto de la imagen de María, acompañada en ocasiones por san Juan, intercediendo por la Humanidad. Así se halla en catedrales europeas, sirviendo como ejemplo una vidriera del deambulatorio de SaintEtienne de Bourges (ca. 1210), donde la Virgen es asistida por los apóstoles; es interesante este caso por la coincidencia del número de apóstoles con la catedral de Ourense, que son nueve, y también de bienaventurados, quince. En fechas más o menos coetáneas se encuentra una escena similar en el portal de Notre-Dame d'Amiens, donde la separación entre justos y pecadores supone el leit motiv del tema, acompañados de la presencia visual del monstruo identificado con el Leviatán como acceso al infierno, y una puerta al Paraíso; en el Cielo, los ángeles se encargan de colocar las coronas a los bienaventurados que lo alcanzan. Esta imagen transmite la nueva espiritualidad que se encontraba en auge durante el siglo XIII, que impulsaba la intercesión de los santos concretos para obtener la salvación del hombre. Así, en fuentes documentales y portadas catedralicias proliferan imágenes de san Juan y María, así como de santos intercesores, especialmente locales.

No obstante, era necesario mostrar las consecuencias de los pecados del fiel. Con intención moralizante se representa en Ourense el prototipo de la lujuria a través de un personaje masculino, al que dos serpientes le oprimen todo el cuerpo, y uno femenino, cuyos pechos son mordidos por dos serpientes. La tradición cristiana distingue entre varios tipos de lujuria asociados a diferentes pecados -fornicación, adulterio, incesto, rapto o estupro- especialmente mencionados a partir del siglo XII por personajes como Pedro Lombardo o el jurista Graciano; durante el siglo XIII todavía santo Tomás de Aquino se hace eco de aquello agregando un sexto tipo, la lujuria como sinónimo de vicio contra natura (Libera 2000: 137138). Interesa especialmente este pecado porque en su momento afectó al rey Salomón y, vinculado al adulterio, también a su padre, el rey David, quienes en Ourense esperarían impertérritos la entrada al paraíso, pero situados frente a la escena, y no incluidos en ella, pues la libido y la ira que ambos habían demostrado en momentos concretos, les obliga a la penitencia para acceder al Paraíso. 


\subsection{David: Domino in regnum uoccatus}

Ambos monarcas bíblicos se habrían ubicado en la contraportada original del pórtico, modificada durante las obras de estabilización del cuerpo occidental durante el siglo XVI. El rey David se encuentra en la actualidad recibiendo al fiel que accede desde la escalinata exterior, y no flanqueando el acceso junto con Salomón, donde presumiblemente se encontraría. Se conjetura su localización originaria bien en los machones laterales del acceso, los cuales en la actualidad todavía conservan las figuras de seis ángeles coronándolos, bien en las jambas del arco de acceso desde el exterior, cuestión que explicaría el canon alargado utilizado para su representación y la elección de labrado en altorrelieve, más que imágenes en bulto redondo. David y Salomón se presentan en una doble lectura. Son figuras de la antigua Ley, anuncian a Cristo como salvador de la Humanidad, al igual que los profetas. Sin embargo existe un interés por reseñar su categoría regia. Ambos actúan como imagen de la monarquía, espejo moral donde pueden reflejarse los príncipes y reyes hispanos, al establecer analogías entre los monarcas bíblicos y los peninsulares, pues el príncipe cristiano debe ser un ejemplo de fe, fortaleza y caridad, entre otras virtudes (Nogales Rincón 2006: 22).

Pero no todos los paralelismos entre los monarcas hispanos del siglo XIII son positivos, pues el rey David, y en mayor medida su hijo Salomón, habían cometido faltas muy graves por las que necesitaron realizar un acto penitencial, fundamentado en tres elementos que demuestran la sinceridad del arrepentimiento y deseos de conversión: un acto de contrición sincero, la confesión y la oración -entendidos como un único elemento (Núñez Rodríguez 2010: 87)- y las obras correspondientes de satisfacción. Dentro de este planteamiento negativo con el que también comulgan los reyes hispanos, sírvanos de ejemplo la respuesta del monarca Alfonso IX a su excomunión a causa de su invalidado matrimonio con doña Berenguela por razones de parentesco, momento en el que entran en conflicto la carne y la gracia divina. Por esta excomunión, buscando congraciarse de nuevo con Dios y el papado, intenta desde este instante doblegarse a su voluntad a través del intencionado gesto de la penitencia, según el cual deberá pedir perdón por sus pecados como el rey David lo implora en su Miserere Mei (Salmo 50) y expiarlos a

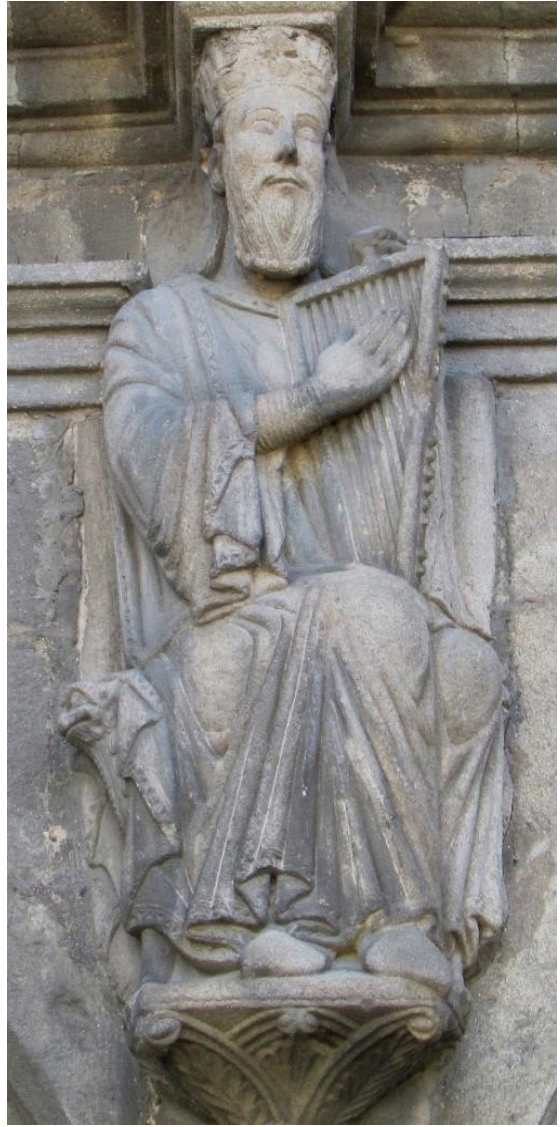

Fig. 2. Rey David. Pórtico del Paraíso. Catedral de Ourense.

través de la peregrinación que realiza a Compostela con esta intención, entendido este gesto como una sumisión a la autoridad papal y de reconciliación con los poderes eclesiásticos. Como obra de satisfacción, Alfonso IX había regalado la basílica de Santiago a Dios, en la búsqueda del perdón de sus pecados (Núñez Rodríguez 2010: 72).

En Ourense, David reposa sus pies calzados sobre una ménsula capitel, los cuales se corresponderían iconográfica y visualmente con los de san Pedro en el interior del pórtico. David está además fuertemente vinculado con las visiones del Infierno, al incluir en su Salmo 18 los terrores del averno, con gran incidencia en homilías y libros penitenciales durante la Edad Media (ibid. 83). El obispo don Lorenzo de Ourense menciona en sus escritos a este monarca bíblico como prototipo de rey justo que, no obstante, fue deformado por el pecado (Núñez Rodríguez 2005: 102), para posteriormente ser reconducido de él a través de la necesaria penitencia. Don Lorenzo señala otras figuras bíblicas como Salomón, Adán, Eva 
o Lázaro que también fueron pecadores que debían reconciliarse con Dios, usando como contrapunto moralizante a la Virgen María o Cristo, ambos sin pecado, y por los que vendrá la salvación de las almas, incluso de aquellas pertenecientes a la Antigua Ley y necesitadas de redención.

E1 Salmo 50, por medio del cual David hace penitencia, resume perfectamente cuál debe ser el sentimiento del pecador consciente y arrepentido de su pecado. Para redimirse, el monarca David, como cualquier otro fiel, necesitó actuar como penitente en acto de contrición, y de este modo se representa en otras muchas latitudes. Así, en la portada norte de la catedral compostelana se ubicaba un relieve del monarca, acompañando a un pseudo-sacrificio de Isaac, en clara relación con el significado de la puerta que los albergaba: anunciar la redención tras el pecado (Silva Verástegui 2010: 125). Del mismo modo, en Sainte- Madeleine de Vézelay se encuentra un capitel en el que David parece hacer acto de contrición al golpearse el pecho, en relación con la reprensión del profeta Natán por su pecado con Betsabé. David no peca solamente de lujuria, sino que quebranta la ley de Dios al conspirar para cometer el asesinato de Urías; además, peca finalmente de orgullo al pretender hacer un censo en Israel, el pueblo incontable de Yahvé (Núñez Rodríguez 2005: 103). Dios le insta a través de Natán para que haga penitencia por todo el oprobio cometido. Tras ello, pide perdón, y es acogido de nuevo en el seno divino en la búsqueda de la humilitas, frente a su anterior soberbia, y la sobrietas, frente a la lujuria (ibid. 107).

Otro elemento que presenta la iconografía de David en Ourense es su variante como monarca músico, en actitud de tocar un instrumento. Se identifica claramente un arpasalterio que sustenta entre sus manos, así como la voluntad de resaltar su carácter regio al ceñir corona en la cabeza y estar sedente sobre silla curulis, cuyos brazos rematan en cabezas de león. No se trata de una iconografía aleatoria, sino que enlaza con la propuesta penitencial del Pórtico. La filosofía medieval entendía la práctica musical como una vía para la redención. Así Boecio proclamaba que la música era armonía, proporción, sentido y orden (Vicens Vidal 2008: 31-33). También san Agustín aconsejaba el empleo de la música en la oración pues el que canta reza dos veces. Asimismo David es el monarca humilde, que se humilla ante Yahvé, capaz de despojarse de sus vestiduras reales $\mathrm{y}$, ataviado con un sencillo efod, alabar a Dios a través de su canto (2 Sam 6, 14).

\subsection{Salomón: sapiens in iudicio, in sententia iustus}

Su hijo Salomón es otro de los modelos de realeza bíblica impuesto en Occidente (Núñez Rodríguez 2008: 304-305). Es interpretado como la imagen de la Iglesia triunfante (ibid. 304), como monarca constructor, ya que fue él quien llevó a cabo la edificación y remate del Templo de Jerusalén. Muchos monarcas occidentales se quieren ver reflejados en él como benefactores o incluso promotores de edificaciones o restauraciones de catedrales, iglesias, monasterios, abadías, conventos o capillas. Al mismo tiempo, encarna también valores políticos e históricos imprescindibles que deberían observar dichos reyes durante la Edad Media. Es, además, paradigma de rey sabio, tal como se registra en varios textos bíblicos.

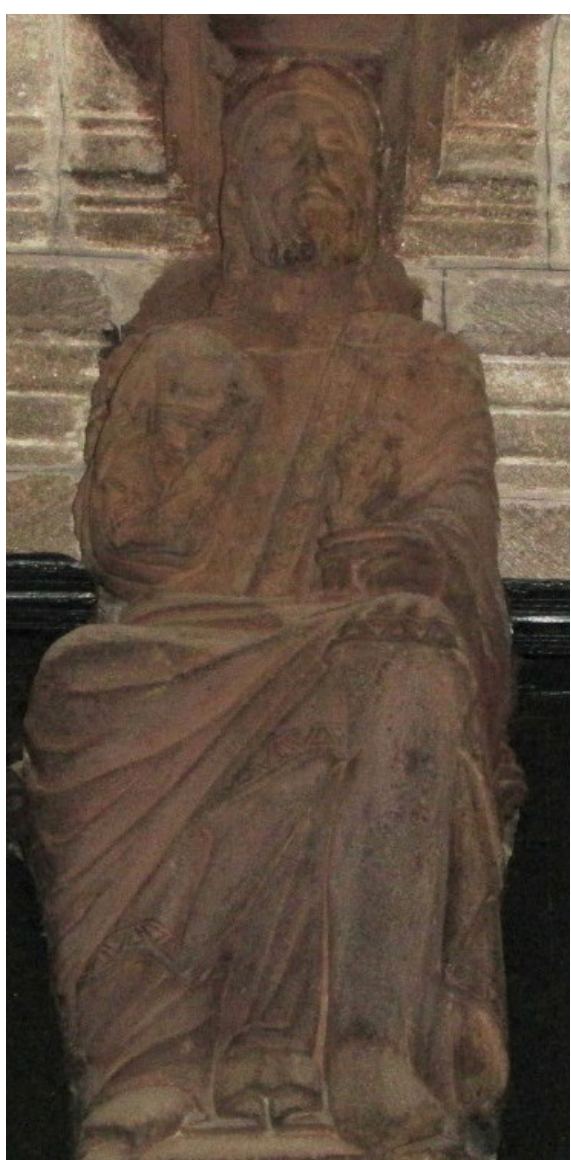

Fig. 3. Rey Salomón. Pórtico del Paraíso. Catedral de Ourense. 
Pese a todas estas características positivas, tampoco se puede olvidar que es un monarca pecador pues, como su padre, cae en la lujuria al tomar setecientas esposas y unas trescientas concubinas; además de ello, su pecado fue todavía mayor por haberse inclinado hacia la idolatría en sus últimos momentos de vida (Reyes 11, 1-13). Como ya ocurriera con David, su hijo Salomón también debe hacer penitencia por todos estos pecados para poder alcanzar la salvación algún día, quedando reflejado en Eclesiastés 7.

En la catedral auriense está representado actualmente en la parte interior del parteluz de la fachada del pórtico del Paraíso, si bien estaría ubicado junto al rey David en los machones laterales. Algunos autores plantearon su identificación con una imagen del Salvador, que habría presidido el desaparecido tímpano central del pórtico acompañado del monarca David (Martínez Sueiro 1913-16: 248). No obstante, más recientemente se planteó al observar los atributos que presenta el personaje (la corona, la vara de justicia) que se trate de Salomón, en base a la figura regia del Obradoiro que porta, como en el caso auriense, un cetro rematado en flor, mientras que la mano derecha se encuentra extendida y no en gesto de bendición (Moralejo Álvarez 1975: 446-447), cuya representación solía estar unida durante la Edad Media a la del rey David. Siguiendo en esta línea, Salomón ciñe sobre su cabeza, como en el caso de su padre, una corona con gemas como decoración, lo cual denota la condición regia del personaje. Para esta identificación también debe tenerse presente la repetición de la imagen de Salomón en dos ocasiones más en la catedral auriense: la primera cronológicamente hablando pertenece a los años del románico y se realizó en la puerta meridional del templo, donde es acompañado por la reina de Saba, y la última, realizada en estilo gótico, en un capitel de la Claustra Nova (Moralejo Álvarez 2004: 32 y Carrero Santamaría 2013: 42-43).

\section{Profetas y patriarcas del Antiguo Testa- mento}

David y su hijo Salomón acuden a la procesión de profetas y apóstoles, encargados de dar testimonio al final de los tiempos, pero también de almas salvadas y pecadores condenados que están siendo juzgados. Desde el punto de vista formal, el estilo de algunos de estos elementos escultóricos roza el goticismo burgalés de la puerta del Sarmental o de la Coronería, lo que ha permitido datar gran parte de las esculturas del pórtico a partir del segundo tercio del siglo XIII.

Asentados sobre zócalos zoomorfos, actualmente desaparecidos, se alzan las columnas que sostienen en el lado norte a los profetas y en el sur a los apóstoles. Asisten al momento final de los tiempos, que acontece en el Pórtico, frente a David y Salomón que solamente lo presenciaban. La procesión comienza con Oseas y Malaquías, situados en el lado norte bajo el arco septentrional, introduciendo ambos la temática del Juicio Final, pues se vinculan con la ruina y el castigo al que es sometido el pueblo de Israel por sus pecados, así como con el anuncio de un ángel purificador enviado por Yahvé para preparar el camino al Juez, con lo que también se relacionan las representaciones que albergan los capiteles situados sobre sus cabezas, una sirena pez encadenando a un centauro y, sobre Malaquías, otro centauro cortando con su hacha ciertos elementos vegetales.

Continúa con un personaje actualmente identificado con el patriarca José por su juventud, su vestimenta y por ser considerada su vida como una prefiguración de la de Cristo. Esta figura está asociada con el pecado de la lujuria representado por la sirena ave de su capitel, y también con la historia de la esposa de Putifar, visualmente presente a través del gesto de desesperación de la imagen del subpedaneum. Los textos del profeta Ezequiel, ubicado a continuación, son un compendio de episodios simbólicos, visiones y oráculos, en los cuales se narran los crímenes que derivaron en la caída y castigo de Jerusalén y Judá, pero destaca sobre todo su profecía por su visión de los Cuatro Vivientes, asociados a la imagen del Tetramorfos, y también aquella sobre lo que ocurrirá en los momentos previos al Juicio, cuando los muertos salgan de sus tumbas. Del mismo modo, Habacuc también pronuncia una serie de sentencias proféticas en las que establece un diálogo con Yahvé, por medio de una lamentación por el pueblo y los castigos que caerán sobre él.

En el lado norte del arco central se representan otros cuatro profetas. Ezequiel, profeta mayor, ha quedado relegado lateral sur del dicho machón, en favor de la incorporación de Jonás, prefiguración de Cristo por su estancia en el interior de un monstruo marino durante 
tres días y tres noches, en los que permaneció orando a Yahvé por su salvación. El sentido de este extraño orden está relacionado con el texto del Decreto de Graciano glosado por el obispo don Lorenzo, donde Jonás es mencionado de modo paralelo al profeta Daniel (Causa 60), y nombrado junto a otros como Malaquías o Isaías. Además, la Causa 58 alude a él en relación a Nínive y sus pecados.

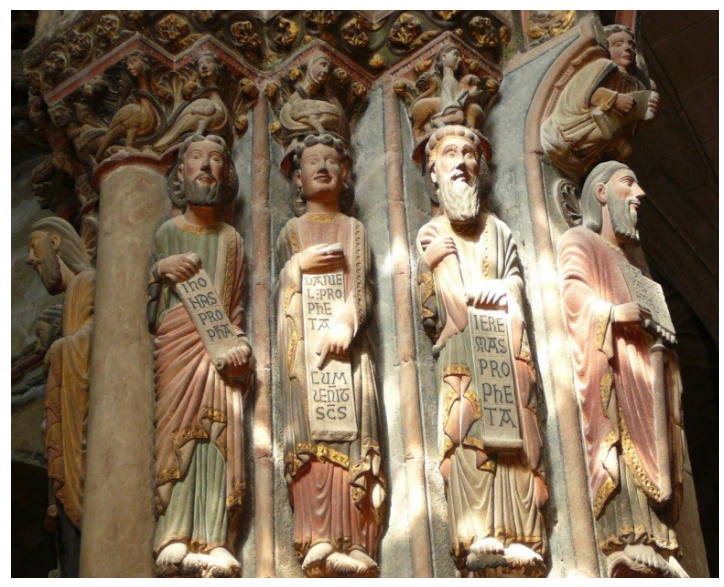

Fig. 4. Profetas Jonás, Daniel, Jeremías e Isaías. Pórtico del Paraíso. Catedral de Ourense

Daniel es conocido sobre todo por sus cuatro visiones apocalípticas que mostraban el Juicio al final de los tiempos, además de prevenir sobre la venida del Mesías. Jeremías, por su parte, es el más trágico entre los profetas mayores $\mathrm{y}$, con su exhortación, persigue animar a mantenerse en una fe auténtica. Frente a la representación compostelana, encabezada por Moisés (Castiñeiras González 2005: 141), se prioriza aquí la figura de Isaías introduciendo a una posible figura mariana, como ya se hacía en otras muchas portadas de las mismas fechas, donde la Virgen se puede encontrar en los tímpanos, ya asunta y coronada en el cielo, acompañada por Cristo.

En este caso, la imagen de María concentraría en sí misma el significado del espacio penitencial en el que se ubica. La casi completa desaparición de los elementos originales del arco central -parteluz, dintel y tímpano-, hace que sea imposible dilucidar cuál era el lugar concreto en el que esta figura se localizaría, si bien la escultura del profeta Isaías flanqueando el acceso y el paso de las almas sin coronar al arco central, del que salen coronadas hacia el arco septentrional en el que se ubicaba el Paraíso, ofrecen la posibilidad de que Cristo, la Asunción o la Coronación de María sean los temas más plausibles que posibiliten que los bienaventurados salgan coronados de la escena timpánica. Hemos planteado la hipótesis de que la posible figura de la Virgen se localizase presidiendo el parteluz, cuyos ascendientes son David y Salomón frente a ella y profetizada y presentada por Isaías.

El planteamiento iconográfico moralizante del conjunto comienza, de este modo, con las figuras regias de David y Salomón. La Causa 60 del Tratado de Penitencia realizado por el obispo don Lorenzo afirma que es necesaria la confesión para alcanzar el Paraíso, todavía vacío y aguardando a los salvados, mencionando a continuación a la serpiente, Caín y Abel, y a David, en clara alusión al demonio que el monarca bíblico consiguió erradicar con su música, sin dejar no obstante al margen el conocimiento de los pecados por los que David fue atormentado. Él, como Jonás, incluido también en este texto, es reprendido y castigado, pero después perdonado tras su expiación, lo que íntimamente relaciona a ambos con esta portada de carácter penitencial, en cuyo espacio porticado deberían permanecer los penitentes durante las eucaristías públicas.

\section{El ritual del perdón}

Era fundamental este espacio durante los períodos de Cuaresma, pues en él los penitentes expiaban sus pecados. El período penitencial se iniciaba el miércoles de Ceniza y remataba en Jueves Santo, durante el ritual del triple Venite en el que el pecador debía humillar su cuerpo postrándolo sobre el suelo, con las manos unidas en señal de oración (Schmitt 1990: 304306), esperando a que el obispo o arzobispo llevase a cabo la ceremonia de reconciliación (Núñez Rodríguez 2010: 83).

Sobre el ritual del perdón, y haciendo de nuevo hincapié en el programa penitencial del pórtico del Paraíso, se encuentra un capitel ubicado en la rosca del arco septentrional en el que dos personajes se toman de la mano dirigiéndose al Edén. Estos dos hombres no proceden del Infierno ni son bienaventurados, pues todos ellos se hallan en el arco opuesto, sino que se trata de una compleja representación como ilustración de la reconciliación de los pecados. El individuo que necesita hacer penitencia a causa de sus faltas debe salir del templo, como ya se adelantaba anteriormente, el Miércoles de Ceniza, acompañado por los 


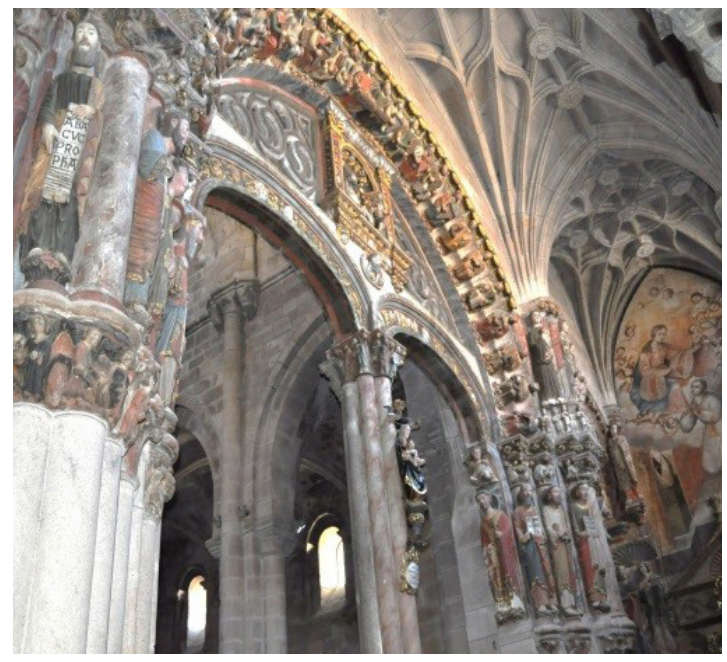

Fig. 5. Pórtico del Paraíso. Catedral de Ourense

demás pecadores, cogidos de la mano y llevados por el obispo, momento en el que éste les impone la ceniza. Santo Tomás de Aquino (1990: III, supl. 9) incide en la necesidad de la expulsión del penitente durante la Cuaresma como recuerdo de aquella de Adán y Eva del Paraíso Terrenal, como consecuencia del Pecado Original. El ritual por el que debe pasar el pecador a la hora de realizar su penitencia es recogido ya por Alfonso X en las Siete Partidas:

Y después de todo esto debe salir el obispo con sus clérigos a la puerta de la iglesia a recibirlos, rezando los salmos penitenciales, y tomarlos por las manos y meterlos dentro: y debe el obispo echarse de preces ante el altar rogando a Dios por ellos yacer en tierra tendidos, llorando y rogando a Dios (...). Y en cuanto los salmos fueren rezados, débese levantar el obispo y poner las manos sobre sus cabezas y poner en ellas ceniza y echar agua bendita sobre ellas (...) diciendo estas palabras (...) «que así como Adán fue echado del Paraíso, así conviene que ellos sean echados de la iglesia por los pecados que hicieron». (Partida Primera, Ley 90)

El tiempo de expiación terminaría el Jueves Santo, cuando se escenifica el mismo acto, pero de regreso tras cumplir la penitencia impuesta: nuevamente los pecadores reconciliados se toman de las manos para acceder al templo y asistir a los Oficios de Semana Santa y Pascua ${ }^{1}$.

\section{Conclusión}

Profetas, patriarcas y monarcas bíblicos configuran un espacio aleccionador basado en la penitencia, junto con los apóstoles, ángeles y ancianos músicos del Apocalipsis, recordando que David y Salomón deben ser imagen memorial con efecto moralizante para aquellos personajes regios que accedan a la catedral y por ello aguardan en el umbral, ante el CristoPuerta, pues por su penitencia fueron considerados dignos de la salvación. Estos monarcas bíblicos no son sino modelos de humildad y sabiduría acordes con la función del pórtico de ser escenario habitual de celebraciones penitenciales tal como refleja su iconografía, cuya fuente primordial es el Tratado de la Penitencia realizado por el obispo promotor de su construcción, don Lorenzo $(\dagger 1248)$. La presencia de los profetas viene a perpetuar que la venida de Cristo fue profetizada por ellos, recordando al fiel o al penitente que vino al mundo a través de la Virgen María.

Según recoge el mismo Tratado, para que se haga efectiva la reconciliación eran necesarios los sacramentos del bautismo y la eucaristía a lo largo de la vida, pero sobre todo la penitencia en cualquier momento. La iconografía representada plantea no solo la necesidad de arrepentimiento durante la Cuaresma, sino que muestra las consecuencias del pecado con la representación de algunos de ellos en los capiteles -lujuria, avaricia, maledicencia-, provocando que el fiel se identifique con ellos y desee acceder a la confesión que se había predicado en el IV Concilio de Letrán (1215), siendo recogida dicha necesidad de confesión por el obispo don Lorenzo en su obra escrita, con el fin de no sufrir los tormentos reservados para los pecadores, figurados en la representación del infierno. Para ello, sabe el fiel penitente que no goza de la misma Gracia que Cristo, que poseía una doble naturaleza humana y divina tal como se figura en el capitel de las tentaciones del parteluz, sino que debe arrepentirse sinceramente y hacer penitencia, siguiendo los ejemplos citados de David y Salomón, para alcanzar el momento del Juicio Final libre de mancha (arco meridional) y que san Miguel y el Juez lo consideren digno de acceder al $\mathrm{Pa}$ raíso (arco septentrional). 


\section{Referencias bibliográficas}

Acosta, Vladimir (1995): Animales e imaginario: la zoología maravillosa medieval. Universidad Central de Venezuela: Dirección de Cultura.

Agustín, San (2007-2012): La ciudad de Dios (ed. R. Ma Marina Sáez). Madrid: Gredos [1 ${ }^{\mathrm{a}}$ ed.].

Alfonso X (1994): Las Siete Partidas. Madrid: Micronet.

Aquino, Santo Tomás de (1990): Suma de Teología. Madrid: Biblioteca de Autores Cristianos.

Conde Cid, Natalia (2013): "El Pórtico del Paraíso como foco receptor de modelos artísticos foráneos: Arte, Poder y Liturgia”, Eikon Imago 1, pp. 71-104.

- (2015): "Laurentius Hispanus o la materializzazione del concetto di Penitenza nella cattedrale di Orense (Galizia)", Compostella 36, pp. 19-25.

- (2016): La catedral de Ourense como imagen del Paraíso en la Edad Media: Arquitectura, cultura visual y espacio para la penitencia. Tesis Doctoral. Santiago de Compostela: Universidade.

Bango Torviso, Isidro (1992): El románico en España. Madrid: Espasa Calpe.

Baschet, Jérôme (1995): "Jugement de l'âme, jugement dernier: contradiction, complémentarité, chevauchement?", Revue Mabillon. Revue internationale d'histoire et de littérature religieuses (Nouvelle Série) 6, pp. 159-203.

Bueno Sánchez, Marisa (2008): “«Quasi per ignem». Claves figurativas de la topografía del Más Allá”, en A. I. Carrasco Manchado y M. P. Rábade Obradó (coords.), Pecar en la Edad Media. Madrid: Sílex Ediciones, pp. 379-408.

Calmet, Agustín (ed.) (1820): Sagrada Biblia. En latín y español, con notas literales, críticas e históricas. Prefacios y disertaciones. México: Imprenta de Galván.

Carrero Santamaría, Eduardo (2013): La Claustra Nova de la Catedral de Ourense. Ourense: Grupo Francisco de Moure.

Castiñeiras González, Manuel (2005): "El Concierto del Apocalipsis en el arte de los caminos de peregrinación", en C. Villanueva Abelairas (coord.), El sonido de la Piedra. Actas del encuentro sobre instrumentos en el Camino de Santiago. Santiago de Compostela: Xunta de Galicia, pp. 119-164.

Chao Castro, David (2005): "Virgen de Belén", en J. M. García Iglesias (ed.), Camino de Paz: mane nobiscum domine. Santiago de Compostela: Xunta de Galicia, pp. 118-121.

- (2002): Estudio histórico-artístico del Pórtico del Paraíso de la catedral de Ourense (Época Medieval). Santiago de Compostela: Xunta de Galicia.

Christie, Yves (1996): "Et vidisedes et sederunt super eas et judiciumdatum est illis. Sur quelques figures trônantes en complément du Jugement dernier au XIIe-XIIIe siècle", en Y. Christie (dir), De l'art comme mystagogie : iconographie du Jugement dernier et des dernières à l'epoque gothique. Poitiers: Centre d’Études Supérieures de Civilisation Médiévale, pp. 155-166.

Delumeau, Jean (2005): Historia del Paraiso (I). El jardin de las delicias. Madrid: Taurus Minor.

Díaz y Díaz, Manuel Cecilio (1985): Visiones del Más Allá en Galicia durante la Edad Media. Santiago de Compostela: Bibliófilos Gallegos.

Erlande-Brandenburg, Alain (2007): La cathédrale de Saint-Denis. Rennes: Éditions Ouest-France.

Fernández González, Etelvina (2013): "Los árboles no dejan ver el bosque. Apreciaciones plásticas e iconográficas en la Edad Media", Cuadernos del CEMYR 21, pp. 11-48.

González Montañés, Julio I. (2002): Drama e iconografía en el arte medieval peninsular (siglos XI-XV). Tesis Doctoral. Madrid: Universidad Nacional de Educación a Distancia.

Grivot, Denis (1986): La cathédrale d'Autun. Ingersheim: SAEP.

Guiance, Ariel (ed.) (2009): Entre el Cielo y la Tierra. Escatología y sociedad en el mundo medieval. Buenos Aires: Instituto Multidisciplinario de Historia y Ciencias Humanas.

Lelong, Charles (1985): "Les portes de la basilique Saint-Martin de Tours", Bulletin de la Société Archéologique de Touraine 46, pp. 159-173.

Libera, Alain de (2000): Pensar en la Edad Media. Barcelona: Anthropos.

Mâle, Émile (2001): El arte religioso del siglo XIII en Francia. Madrid: Encuentro.

Martínez Sueiro, Manuel (1913-1916): "El autor del Pórtico del Paraíso", Boletín de la Comisión de Monumentos Histórico-Artísticos de Orense V, pp. 247-253.

Moralejo Álvarez, Serafín (1975): Escultura gótica en Galicia (1200-1350). Santiago de Compostela: Universidade. 
- (1975): Escultura gótica en Galicia (1200-1350). Resumen de la memoria presentada para la obtención del grado de Doctor. Santiago de Compostela: Universidade.

— (2004): Iconografía gallega de David y Salomón. Santiago de Compostela: Agencia Gráfica.

Nogales Rincón, David (2006): "Los espejos de príncipes en Castilla (siglos XIII-XV): un modelo literario de la realeza bajomedieval", Medievalismo 16, pp. 9-39.

Núñez Rodríguez, Manuel (2005): "David, el canticum y la iucunditas en el siglo XII”, en C. Villanueva Abelairas (coord.), El sonido de la Piedra. Actas del encuentro sobre instrumentos en el Camino de Santiago. Santiago de Compostela: Xunta de Galicia, pp. 89-117.

- (2008): "Reflexión sobre el Pórtico del Paraíso en concurrencia con el peregrinaje", Anuario Brigantino 31, pp. 304-305.

- (2010): "El Especulum morale del Rex Gratia Dei Alfonso IX a la luz del pórtico de la Gloria", POTESTAS. Revista del Grupo Europeo de Investigación Histórica 3, pp. 69-98.

— (2011): A la búsqueda de la memoria. Los tres pórticos mayores de la Basílica de Gelmírez. Santiago de Compostela: Consorcio de Santiago.

Pérez Higuera, María Teresa (1988): "El Jardín del Paraíso: paralelismos iconológicos en el arte hispano musulmán y cristiano medieval", Archivo Español de Arte 61/241, pp. 37-52.

Sánchez Ameijeiras, María Rocío (2001): "La portada del Sarmental de la catedral de Burgos", Materia, 1, L'estil, pp. 161-198.

- (2008): "O entorno imaxinario do rei: cultura cortesá e/ou cultura clerical en Galicia en tempos de Alfonso IX", en F. López Alsina et alii (coords.), Alfonso IX e a súa época: Pro utilitate regni mei. A Coruña / Madrid: Concello da Coruña / Ministerio de Cultura, Sociedad Estatal de Conmemoraciones Culturales, pp. 307-325.

Schmitt, Jean-Claude (1990): La raison des gestes dans l'Occident médiéval. París: Gallimard.

Sebastián López, Santiago (1986): El fisiólogo atribuido a san Epifanio. El bestiario toscano. Madrid: Tuero.

Sicart Giménez, Ángel (1983): "La intervención de Rodrigo Gil en la remodelación de la catedral de Orense", Boletín del Seminario de Estudios de Arte y Arqueología XLIX, pp. 287-296.

Silva Verástegui, María Soledad (2010): "Espacios para la penitencia pública y sus programas iconográficos en el Románico Hispano", Clio y Crimen 7, pp. 111-135

Verdier, Philippe (1980): Le couronnement de la Vièrge: les origines et les premiers développements d'un thème iconographique. Paris-Vrin: Institut d'Études Albert-le-Grand.

Vicens Vidal, Francesc (2008): Diabolus in música. Formes de pecat i redempció a la iconografía musical del romànic hispànic. Palma: L'Hiperbòlic.

Villette, Jean (1994): Les portails de la cathédrale de Chartres. París: Garnier.

Yzquierdo Perrín, Ramón, Miguel Ángel González García y José Hervella Vázquez (1993): La catedral de Orense. León: Edilesa. 